\title{
Ecology and Diversity of Plankton in Kotmale Reservoir, Sri Lanka
}

\author{
A.L. Warusawithana ${ }^{1}$ and S.K. Yatigammana ${ }^{2 *}$ \\ ${ }^{1}$ Medical Research Institute, P.O.Box 527, Dr Danister De Silva Mawatha, Colombo - 08, \\ Sri Lanka \\ ${ }^{2}$ Department of Zoology, Faculty of science, University of Peradeniya, Peradeniya (20400), \\ Sri Lanka
}

*Correspondence (sudharma_y@yahoo.com)
iD $h$ http://doi.org/10.4038/sljas.v24i1.7565

\begin{abstract}
Present study investigated the relationship between plankton communities and environmental variables in five different locations of the Kotmale Reservoir during the period of June 2008 to May 2011. A total of 123 plankton species were recorded with 85 species of phytoplankton and 38 species of zooplankton. The relative abundance data indicate that Aulacoseira granulata (31.06\%), Botryococcus braunii (12.34\%) and Microcystis sp. (11.93\%) were the dominant phytoplankton species while Acanthocystis turfacea (52.22\%) was the dominant zooplankton species. Staurastrum cingulum was the dominant species in sites where the immediate catchment is covered with reservation forest with no significant inflow streams. Aulacoseira granulata, Fragellaria capucina and Navicula sp. were abundant in locations where the highest total phosphorus (TP) values were recorded. The main inflow streams, Puna Oya and Pundalu Oya appear to bring nutrient rich waters from its catchment with dense tea estates, agricultural lands, industries and villages. Microcystis sp. was abundant in locations where the highest values for TP, dissolved phosphorus (DP), ammonia, conductivity and turbidity were recorded. Botryococcus braunii was dominant in the location where Puna Oya reaches the reservoir. Staurastrumlepta canthum was abundant in the location located closer to the dam where the water body mostly contains limnetic characteristics. Among the zooplankton, cladocera species were abundant in sites where Staurastrum cingulum was identified. Rotifers and ciliate protozoans were identified closer to the dam and at the sites with high dominance of Microcystis sp. Accordingly, it was apparent that the distribution and abundance of these plankton species depend on the prevailing environmental conditions which ultimately show their ability to use as environmental indicators.
\end{abstract}

Keywords: Eutrophication, Plankton, Tropical reservoirs, Water quality

\section{INTRODUCTION}

In Sri Lanka, reservoir construction was initiated in ancient times for conserving water for irrigation and domestic purposes. However, with the development of technology, reservoirs were constructed for the purpose of generating hydroelectricity as a sustainable, renewable source of energy. Majority of these reservoirs are established by constructing large dams across the Mahaweli River and therefore, has caused distinct changes to river flow (Fernando 1993) as well as to the local biodiversity. Among these reservoirs, the Kotmale Reservoir is the most upstream reservoir which is constructed under the Mahaweli development scheme of Sri Lanka. It is located in the central highlands of Sri Lanka at an elevation of $640-762 \mathrm{~m}$, above sea level with a geographlical position of $07^{0} 03^{\prime} \mathrm{N}$ to $07^{0}$ $05^{\prime} \mathrm{N}$ and $80^{\circ} 36^{\prime} \mathrm{E}$ to $80^{\circ} 41^{\prime} \mathrm{E}$ (Abeysinghe 2005). The climate of this area is mainly determined by the south-west monsoon from May to September and by the north-east monsoon from November to March (Abeysinghe 2005). The reservoir is harvesting the Mahaweli waters to reach the main aim of generating hydroelectrically power to boost the national grid of 14,588 GW (Ministry of Power and Renewable Energy 2018). In addition to hydroelectric power generation, the reservoir acts as a storage reservoir to satisfy irrigation water requirements, flood control, stabilizing the water diverted at Polgolla barrage towards Amban river basin (Piyasiri 1995; Abeysinghe 2005). The reservoir covers a land area of $22.7 \mathrm{~km}^{2}$ from both Kandy and Nuwara Eliya districts and is located between Tispane and Kadadora hills. The reservoir regulates a volume of $174 \mathrm{Mm}^{3}$ of water, at full capacity. Once filled at full capacity the reservoir has a surface area of $250838 \mathrm{~m}^{2}$ with an average storage capacity of $792872 \mathrm{~m}^{3}$ (Piyasiri and Chandrananda 1998; Abeysinghe 2005). It receives water from its catchment of approximately $563 \mathrm{~km}^{2}$ via three main tributaries: Pundalu Oya, Puna Oya, Kotmale Oya and nearly nine minor tributaries: Makaduru 


\section{A.L. Warusawithana and S.K. Yatigammana}

Oya, Kahahena Ella, Raja Ella, KudaOya, Gerande Ella, Helaboda Ella-1, Helaboda Ella11, Ramboda Ella-1 and Ramboda Ella-11 (Abeysinghe 2005). However, with the development of agriculture and technology, these tributaries which run through the dense tea estates, other agricultural lands and factory areas are now known to bring nutrient rich surface runoff into the reservoir. Although it is obvious to influence the species diversity, seasonal variation and the population structure of, especially plankton in the reservoir, it may have also caused alteration of the limnological condition of the reservoir and ultimately would damage the health of the reservoir. For an instance, during a severe drought in 1991, the reservoir water level dropped and a thick bloom of Microcystis aeruginosa has been observed in the upstream location initially which was gradually shifted towards the dam due to wind action (Piyasiri 1995).

Generally, physico-chemical nature of the reservoirs is determined by hydro geochemistry of the drainage basin, landscape characteristics of the inundated land and geographical position of the water body (Silva and Schiemer 2001). However, recently, due to the intensification of human activities, many reservoirs in Sri Lanka are facing the danger of cultural eutrophication as well as other forms of pollution (Costa and De Silva 1995). To understand the impact of anthropogenic activities on these reservoirs, it is necessary to understand current limnological conditions along with the information on existing indicator organisms.

The basis of individual species as bio indicators lies in their preference for (or tolerance of) particular habitats, plus their ability to grow and out-compete organisms under particular conditions of water quality (Dokulil 2003; Bellinger and Sigee 2010). Presence of such species in a given habitat will then indicate that one or more physical and/or chemical parameters are within the tolerance limits of that species. This concept of indicators can be extended beyond the presence/absence by relating abundance, the biomass of algal species to the environmental impact in general or specific stress symptoms in particular. The indicator species then become a "bio-sensor" for the bioassay of environmental contamination (Dokulil 2003).

It is generally accepted that the communities of aquatic organisms, such as planktons can serve as bio-indicators of water quality (Wu 1984; Dokulil2003). Some plankton species have special characteristics to be used as a good indicator species: having a narrow ecological range, showing a rapid response to environmental change (e.g. change in morphology, change in color, production of toxins, rapid multiplication and creating blooms), having well defined taxonomy, reliable identification (using routine laboratoryequipment), and having a wide geographical distribution. Several species of both phytoplankton and zooplankton have been long used as effective bio-indicators that are sensitive to biological changes as well as environmental changes (such as eutrophication, acidification, and salinization) of the media that they live (Smol 2002). Such organisms are monitored for changes (biochemical, physiological or behavioral) that may indicate a problem within their ecosystem. They can tell us about the cumulative effects of different pollutants in the ecosystem and about how long a problem may have been present, which the physical and chemical testing cannot. Accordingly, the abundance of plankton communities can be used to determine the health of an aquatic ecosystem by understanding community structure of planktonic organisms such as cladocera, diatoms and chironomids (Hall et al. 1999; Smol 2002; Bos and Cumming 2003; Yatigammana and Cumming 2017).

Although, many research were undertaken in order to understand the taxonomy of aquatic biota parallel to physic-chemical features in various freshwater bodies of Sri Lanka including the hydroelectric power generating reservoirs (e.g. Fernando 1978; Rajapaksha 1981; Kamaladasa and Jayatunga 2007; Yatigammana and Cumming 2017), studies leading to investigate the changes of biota in relation to changes of physic-chemistry of the water, mainly due to natural and human impacts are poorly understood. On the other hand, chemical and physical changes of a lake lead to changes in biological composition and may ultimately affect the ecological balance of the system. Therefore, it has become an urgent need to conduct such investigations on recently constructed reservoirs in Sri Lanka to avoid possible future environmental hazards that these reservoirs could face. Accordingly, our study was designed to assess the use of indicator organisms to determine environmental changes in the Kotmale Reservoir. 


\section{A.L. Warusawithana and S.K. Yatigammana}

\section{MATERIALS AND METHODS}

\section{Study area}

For the current study, five sampling locations ("A", "B", "C", "D" and "E") with different types of environmental conditions were identified in the left and right banks of the
Kotmale Reservoir, along the longitudinal gradient by considering catchment characteristics and presence of inflow canals. Twenty study sites $\left(\mathrm{A}_{1}, \mathrm{~A}_{2}, \mathrm{~A}_{3}, \mathrm{~A}_{4}, \mathrm{~B}_{1}, \mathrm{~B}_{2}, \mathrm{~B}_{3}, \mathrm{~B}_{4}, \mathrm{C}_{1}, \mathrm{C}_{2}, \mathrm{C}_{3}\right.$, $\mathrm{C}_{4}, \mathrm{D}_{1}, \mathrm{D}_{2}, \mathrm{D}_{3}, \mathrm{D}_{4}, \mathrm{E}_{1}, \mathrm{E}_{2}, \mathrm{E}_{3}$ and $\mathrm{E}_{4}$ ) were randomly selected from the five study locations to obtain the maximum representation of the reservoir (Figure 1).

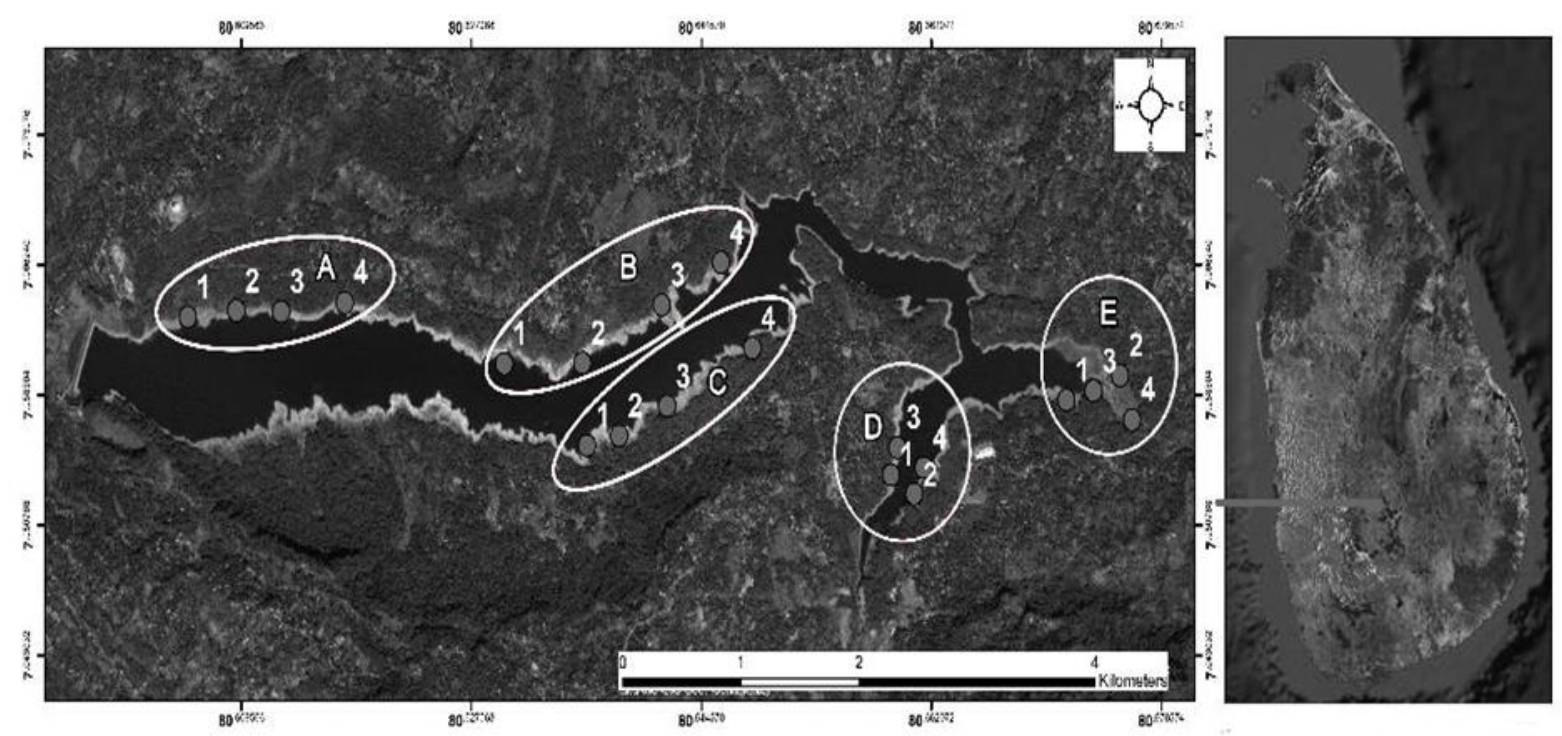

Fig 1The map of the Kotmale reservoir in Sri Lanka with identified five different localities (locations) and twenty sampling sites

\section{Sampling procedure}

\section{Biological data}

Reservoir plankton samples were collected once a month for one year (June 2008 - May 2009), and quarterly for the second and third years (June 2009 - May 2011) in each study sites, using a gravity corer $(70 \mathrm{~mm}$ inner diameter with 600 mm length) and plankton nets (mesh size 34 $\mu \mathrm{m})$, respectively. Plankton sample was collected, preserved and analysed following the standard techniques/methods (Hann 1990; Verschuren et al. 2000) and identified using standard identification guides (Freeman and Craston 1980; Dodson and Frey 1991; Kinross 2000; Kutikova 2002; Baker 2012). Finally, the number of individuals in each taxon was enumerated for the calculation of relative abundance (RA).

\section{Limnological data}

Most of the sampling and field measurements were done during the morning and/or late evening hours to avoid the effect of winds. Water samples from a depth of $\sim 0.05 \mathrm{~m}$ were obtained from each sampling station for laboratory analyses of nutrients (nitrite, nitrate, ammonia, total-phosphorous and dissolved-phosphorous), alkalinity, dissolved oxygen (DO), sulphate and chlorophyll-a. Sample collection, preservation and analysis were done following the American Public Health Association (APHA)-1992 standard methods for the examination of water and wastewater (18th edition, 1992). Nitrite, nitrate, ammonia, total-phosphorous, dissolvedphosphorous and chlorophyll-a were measured using a spectrophotometric method. Alkalinity and DO were measured using titrimetric method and sulphate was measured using nephelometric method. For the laboratory analyses, water samples were collected once in three months, for the first year (June 2008 - May 2009) in the dry season and, for the second and third years (June 2009 - May 2011) in the wet season. On-site temperature and conductivity were measured using calibrated Thermo Orion $\odot-$-Model 105, the measurements of $\mathrm{pH}$ were obtained using Orion ${ }^{\circledR}$-Model 230A portable $\mathrm{pH}$ meter, turbidity measurements were done using portable EUTECH○-TN-100 turbidity meter. On-site 


\section{A.L. Warusawithana and S.K. Yatigammana}

measurements were taken once a month for the first year (June 2008 - May 2009), and quarterly during the second and third years (June 2009 May 2011) at $\sim 0.05 \mathrm{~m}$ below the water surface in each sampling site.

\section{Data analysis}

Identified phytoplankton and zooplankton species were categorized into five groups and seven groups, respectively, for the convenience of exploring the importance of plankton as bioindicators. Thus, phytoplankton groups include blue green algae (BGA), desmids, diatoms, dinoflagellates and other green algae (OGA = except desmids and diatoms). Zooplankton groups include rotifers, copepods, cladocerans, ciliates, protozoan, nematodes (accidental plankton), and insect larvae (accidental plankton). Relative abundance (RA) of each plankton group and each plankton species was calculated (Microsoft Excel-2007). Meanwhile, spatial and temporal variations of plankton groups were analyzed by two-way ANOVA in Minitab (v14). The RA of each genus/species was compared with physic-chemical variables using XLSTAT (v7.5). Canoco for windows (v5) was used to analyze and identify which environmental variable (explanatory variable) would be the best in explaining the species variation (response variable). Canonical ordination techniques were used to assess the relationship between the measured environmental variable and species composition. Systat (v9) was used to understand the correlation between measured environmental variables. A canonical correspondence analysis (CCA) was carried out to understand the species preference to each environmental variable. Finally, the data was used to discriminate the potential of using encountered organisms as indicators for environmental assessment.

\section{RESULTS}

\section{Distribution and abundance of plankton}

A total of 123 plankton species: 85 phytoplankton and 38 zooplankton species were encountered. Not only for the reservoir, but also for five study locations, the recorded RA of phytoplankton ( $98.97 \%)$ was comparatively much higher than that of zooplankton (1.03\%), with the approximate ratio of phytoplankton to zooplankton is 99:1. Out of 85 identified phytoplankton species, only 15 species were recorded with a RA of more than $1 \%$ which include Aulacoseira granulata (31.06\%), Botryococcus braunii (12.34\%), Cosmarium portianum (2.15\%), Cosmarium incertum (1.54\%), Fragillaria capucina (1.11\%), Staurastruma ciculiferum (4.24\%), Staurastrum cingulum (8.04\%), Staurastrum coarctatum (1.35\%), Staurastrum dickiei (1.03\%), Staurastrum grallotorium (2.10\%), Staurastrum leptacanthum (7.72\%), Staurastrum pentacerum (1.06\%), Staurastrum chaetoceras (4.34\%), Navicula sp. (2.19\%) and Microcystis sp. (11.93\%). Among them, the highest diversity was encountered for Staurastrum sp. with 18 species recorded. Out of 38 identified zooplankton species, only 12 species were recorded with a RA of more than $1 \%$. They are Acanthocystis turfacea (52.22\%), Alona rectangula (1.31\%), Alona verrucosa (1.62\%), Amoeba proteus (2.96\%), Chydorus sphaericus (1.81\%), Cyclops parasinus (2.50\%), Dadayama crops (1.52\%), Diaptomus viduus (1.70\%), Philodina citrina (1.16\%), Nauplius larvae (1.69\%), Nematode sp. A (unidentified) (3.13\%) and Protozoan sp. A (unidentified) (23.34\%).

Identified phytoplankton groups: desmids $(36.82 \%)$ and diatoms $(36.67 \%)$ were widely distributed throughout the reservoir with higher RA. The group dinoflagellate was restricted to several locations with the lowest RA $(0.03 \%)$. Study location "A" $(60.54 \%)$ and "B" $(78.62 \%)$ were dominated by desmids. Location "E" was dominated by diatom $(84.68 \%)$. Location "D" was dominated by OGA (45.41\%). However, in location "C", BGA (29.15\%), desmids $(31.71 \%)$ and diatoms $(30.72 \%)$ were distributed nearly at equal abundance. Among the identified zooplankton groups, protozoa $(79.42 \%)$ showed the highest RA compared to other groups. However, ciliates were the least abundant group (1.10\%). Except protozoans, cladocera also showed a comparatively high abundance $(7.75 \%)$. RA of copepoda, insect larvae, nematoda and rotifer were $4.30 \%, 2.05 \%$, $3.13 \%$ and $2.26 \%$, respectively. Location " $\mathrm{A}$ " was dominated by rotifers $(33.33 \%)$, and locations "B" (70.57\%), "C" (53.65\%) and " $D$ " $(92.98 \%)$ were dominated by protozoans (Figure 2). In location "D", except the highest dominance of protozoa, all the other zooplankton groups were equally distributed. Location "E" was dominated by cladocera $(48.30 \%)$. Greater level of protozoa $(92.98 \%)$ with a very low level of cladocera $(2.05 \%)$ was recorded in location " $D$ ". In location "A" and "E", low level of protozoa (5.73\% and $27.55 \%$, respectively) with high level 


\section{A.L. Warusawithana and S.K. Yatigammana}

of cladocera ( $22.40 \%$ and $48.30 \%$, respectively) were recorded. Although RA of phytoplankton and zooplankton groups showed a remarkable variation along the spatial gradient (among the locations and sites), the variation was not well conspicuous along the temporal gradient (during three consecutive years) (Figure 2). The significant effect of location (A, B, C, D, and E), and time $\left(1^{\text {st }}, 2^{\text {nd }}\right.$ and $3^{\text {rd }}$ year $)$ on the distribution
Blue Green Algae

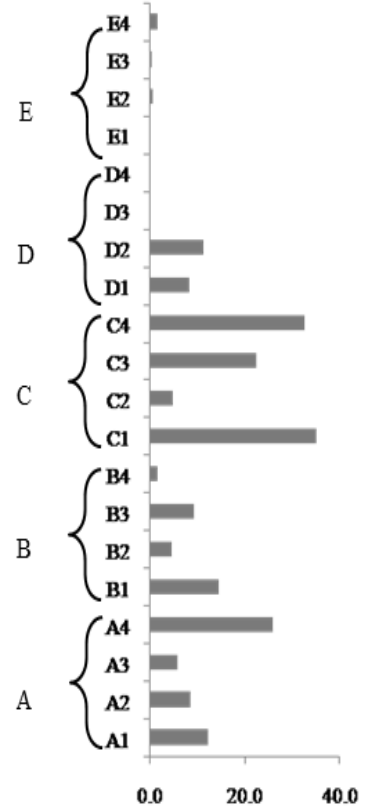

Desmid

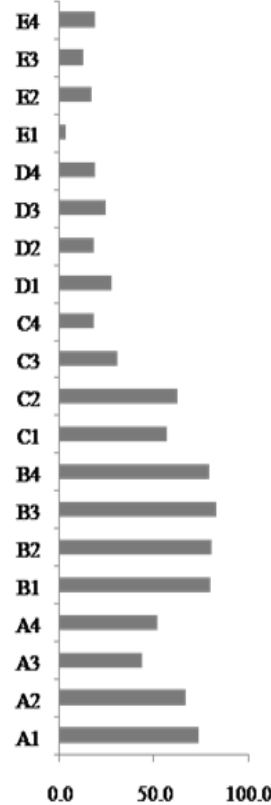

and abundance of each plankton group is listed in Table 1 .

\section{Diatom}

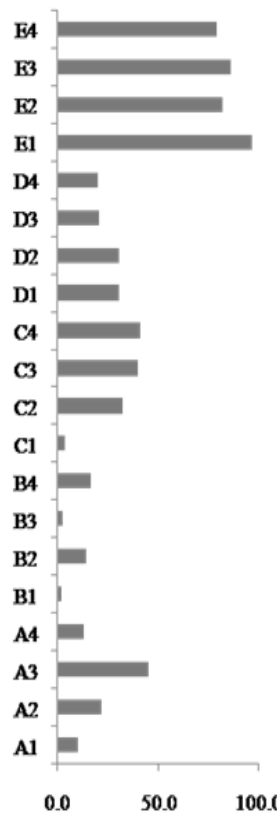

Dinoflagellate

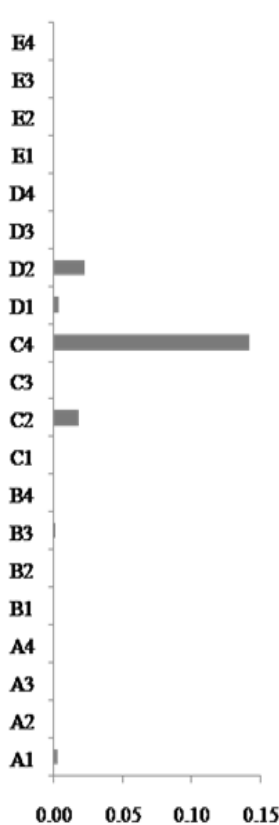

Other Green Algae

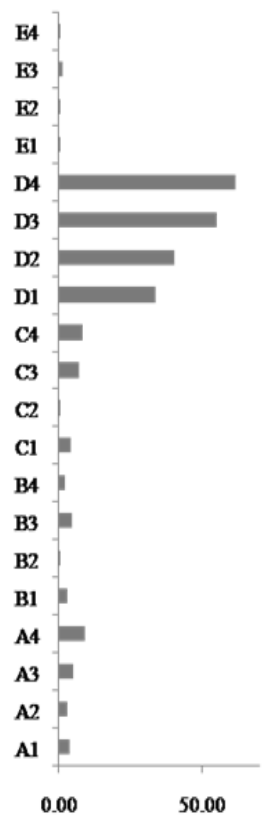

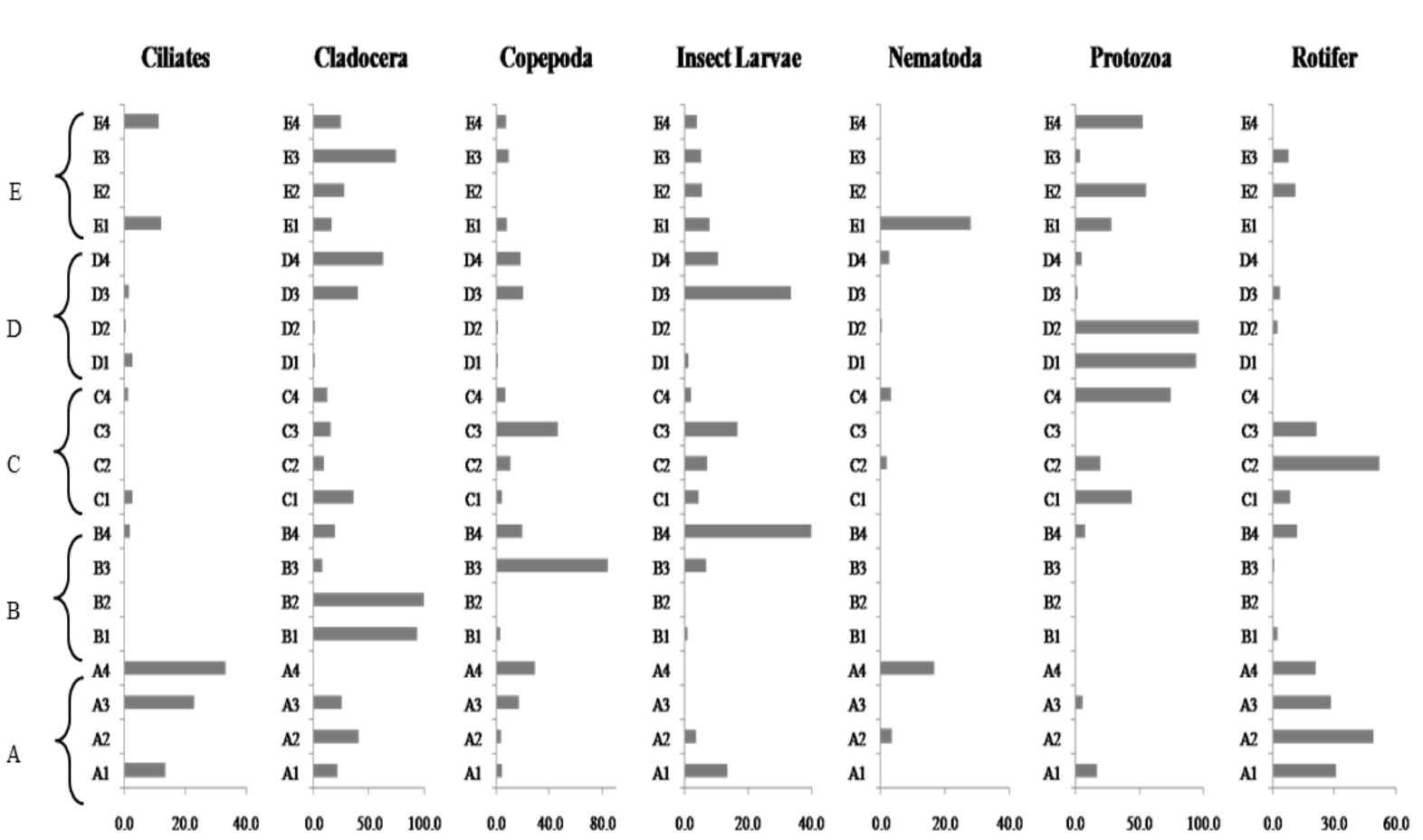

Fig 2 Distribution of RA of dominant phytoplankton (top) and zooplankton (bottom) groups within study site of the Kotmale Reservoir 


\section{A.L. Warusawithana and S.K. Yatigammana}

Table 1 Calculated $p$ value for RA of plankton vs. location / sites of locations and time (year)

\begin{tabular}{|c|c|c|c|c|c|c|c|c|}
\hline \multirow{3}{*}{$\begin{array}{l}\text { Identified Plankton } \\
\text { Group }\end{array}$} & \multicolumn{8}{|c|}{$\begin{array}{l}\text { Calculated } p \text { value }(\alpha=0.05) \text { for RA of plankton vs.(a) location / (b)time (year)/ (c) } \\
\text { interaction between location and time / (d) sites of location }\end{array}$} \\
\hline & \multirow{2}{*}{ (a) } & \multirow{2}{*}{ (b) } & \multirow{2}{*}{ (c) } & \multicolumn{5}{|c|}{ (d) } \\
\hline & & & & A & B & $\mathrm{C}$ & $\mathrm{D}$ & $\mathrm{E}$ \\
\hline \multicolumn{9}{|l|}{ Phytoplankton } \\
\hline Blue green algae & 0.000 & 0.876 & 0.987 & 0.004 & 0.009 & 0.001 & 0.000 & 0.002 \\
\hline Desmids & 0.000 & 0.865 & 1.000 & 0.000 & 0.561 & 0.000 & 0.021 & 0.002 \\
\hline Diatoms & 0.000 & 0.974 & 1.000 & 0.000 & 0.000 & 0.000 & 0.001 & 0.001 \\
\hline Dinoflagellate & 0.033 & 0.604 & 0.951 & 0.455 & --- & 0.032 & 0.082 & --- \\
\hline Other green algae & 0.000 & 0.853 & 0.996 & $\mathbf{0 . 0 3 9}$ & 0.002 & 0.000 & 0.000 & 0.099 \\
\hline \multicolumn{9}{|l|}{ Zooplankton } \\
\hline Ciliates & 0.000 & 0.679 & 0.577 & 0.154 & 0.455 & 0.017 & 0.502 & 0.188 \\
\hline Cladocera & 0.035 & 0.967 & 0.999 & 0.021 & 0.000 & 0.011 & 0.001 & 0.000 \\
\hline Copepoda & 0.209 & 0.772 & 0.999 & 0.054 & 0.000 & 0.048 & 0.016 & 0.217 \\
\hline Insect larvae & 0.769 & 0.699 & 0.962 & 0.340 & 0.000 & 0.111 & 0.064 & 0.992 \\
\hline Nematoda & 0.170 & 0.876 & 0.922 & 0.013 & --- & 0.124 & 0.457 & 0.008 \\
\hline Protozoa & 0.001 & 0.947 & 0.999 & 0.122 & 0.008 & 0.000 & 0.000 & 0.014 \\
\hline Rotifer & 0.000 & 0.631 & 0.949 & 0.468 & 0.003 & 0.008 & 0.235 & 0.005 \\
\hline
\end{tabular}

A: Location-A; B: Location-B; C: Location-C; D: Location-A; E: Location-E (values in bold are significantly different from each other at $p=0.05$ ).

\section{Limnological (physic-chemical) variables of the Kotmale Reservoir}

Study locations showed a variation in their average recorded limnological (physicchemical) variables during wet and dry seasons,as summarized in Table
2.Accordingly, location "D"showed a high level of total phosphorous with the average values of $36.2 \mu \mathrm{g} \mathrm{l}^{-1}$ during the wet season and $42.3 \mu \mathrm{g} \mathrm{l^{-1 }}$ during the dry season. Location " $\mathrm{A}$ " showed a relatively high level of nitrite content, especially during the dry season $\left(125.3 \mu \mathrm{g} \mathrm{l}^{-1}\right)$.

Table 2. Average limnological (physic-chemical) variables of the Kotmale Reservoir during wet and dry seasons

\begin{tabular}{|c|c|c|c|c|c|c|c|c|c|c|c|c|c|c|c|}
\hline \multirow{2}{*}{$\begin{array}{l}\text { Physico } \\
\text { chemical } \\
\text { Variables }\end{array}$} & \multicolumn{2}{|c|}{ A } & \multicolumn{2}{|c|}{ B } & \multicolumn{2}{|c|}{$\mathrm{C}$} & \multicolumn{2}{|c|}{$\mathrm{D}$} & \multicolumn{2}{|c|}{ E } & \multicolumn{2}{|c|}{ Average } & \multicolumn{2}{|l|}{ Range } & \multirow{2}{*}{ Total Mean \pm SE } \\
\hline & Wet & Dry & Wet & Dry & Wet & Dry & Wet & Dry & Wet & Dry & Wet & Dry & Min. & Max. & \\
\hline $\mathrm{T}$ & 25.2 & 29.0 & 24.3 & 25.3 & 26.3 & 26.5 & 27.5 & 28.0 & 26.0 & 27.5 & 26.0 & 27.3 & 24.3 & 29.0 & $26.6 \pm 1.4$ \\
\hline TB & 2.4 & 5.3 & 3.3 & 2.4 & 14.5 & 16.2 & 16.3 & 12.9 & 4.3 & 5.2 & 8.2 & 8.4 & 2.4 & 16.3 & $8.3 \pm 5.9$ \\
\hline PH & 7.9 & 8.3 & 7.2 & 7.2 & 8.3 & 8.1 & 7.8 & 7.9 & 7.6 & 7.8 & 7.8 & 7.9 & 7.2 & 8.3 & $7.8 \pm 0.4$ \\
\hline $\mathrm{CON}$ & 57.0 & 62.0 & 48.0 & 52.0 & 78.0 & 86.3 & 80.5 & 82.0 & 52.0 & 55.6 & 63.1 & 67.6 & 48.0 & 86.3 & $65.3 \pm 14.7$ \\
\hline ALK & 25.6 & $\begin{array}{l}28.6 \\
125 .\end{array}$ & 22.4 & 26.3 & 36.0 & 35.2 & 28.6 & 30.2 & 33.5 & 32.6 & 29.2 & 30.6 & 22.4 & 36.0 & $29.9 \pm 4.4$ \\
\hline NTI & 45.9 & 3 & 48.2 & 50.3 & 52.3 & 85.3 & 56.3 & 59.8 & 46.2 & 42.5 & 49.8 & 72.6 & 42.5 & 125.3 & $61.2 \pm 25.6$ \\
\hline NTA & 0.8 & 1.3 & 1.2 & 1.4 & 0.8 & 2.3 & 1.6 & 2.5 & 1.6 & 2.6 & 1.2 & 2.0 & 0.8 & 2.6 & $1.6 \pm 0.7$ \\
\hline $\mathrm{AM}$ & 58.9 & 65.4 & 62.3 & 63.0 & 65.2 & 84.1 & 65.0 & 72.0 & 63.2 & 65.0 & 62.9 & 69.9 & 58.9 & 84.1 & $66.4 \pm 7.0$ \\
\hline TP & 23.7 & 26.3 & 20.5 & 30.5 & 32.5 & 35.2 & 36.2 & 42.3 & 28.6 & 33.5 & 28.3 & 33.6 & 20.5 & 42.3 & $30.9 \pm 6.4$ \\
\hline DP & 2.9 & 3.3 & 3.2 & 5.2 & 4.3 & 5.3 & 3.6 & 5.2 & 1.6 & 2.6 & 3.1 & 4.3 & 1.6 & 5.3 & $3.7 \pm 1.3$ \\
\hline SO & 0.8 & 0.9 & 0.8 & 0.9 & 1.0 & 1.3 & 1.3 & 0.9 & 1.7 & 1.9 & 1.1 & 1.2 & 0.8 & 1.8 & $1.2 \pm 0.4$ \\
\hline DO & 6.3 & 6.8 & 7.4 & 8.5 & 6.2 & 6.2 & 6.9 & 7.6 & 8.2 & 8.1 & 7.0 & 7.4 & 6.2 & 8.5 & $7.2 \pm 0.9$ \\
\hline $\mathrm{CH}$ & 26.7 & 54.3 & 32.9 & 50.6 & 56.9 & 65.0 & 23.5 & 26.3 & 20.4 & 18.2 & 32.1 & 42.9 & 18.2 & 65.0 & $37.5 \pm 17.4$ \\
\hline
\end{tabular}

A, Location-A; B, Location-B; C, Location-C; D, Location-D; E, Location- E; Wet, Wet season; Dry, Dry season;T, Temperature $\left({ }^{\circ} \mathrm{C}\right)$; TB, Turbidity (NTU); $\mathrm{PH}, \mathrm{pH}$ value; CON, Conductivity $\left(\mu \mathrm{S} \mathrm{cm}^{-1}\right)$; ALK, Total Alkalinity $\left(\mathrm{mg} \mathrm{l}^{-1}\right)$; NTI, Nitrite $\left(\mu \mathrm{g}^{\left.1^{-1}\right)}\right.$; NTA, Nitrate $\left(\mathrm{mg} \mathrm{l}^{-1}\right)$; AM, Ammonia $\left(\mu \mathrm{g}^{-1}\right)$; Total Phosphorous, TP ( $\left.\mu \mathrm{g} \mathrm{l}^{-1}\right)$; DP, Dissolved Phosphorus $\left(\mu \mathrm{g} \mathrm{l}^{-1}\right)$; SO, Sulphate $\left(\mathrm{mg} \mathrm{l}^{-1}\right)$, DO, Dissolved Oxygen $\left(\mathrm{mg} \mathrm{l}^{-1}\right)$; $\mathrm{CH}$, chlorophyll-a $\left(\mu \mathrm{g} \mathrm{l}^{-1}\right)$ (values in bold are significantly different from its total mean). 


\section{A.L. Warusawithana and S.K. Yatigammana}

Furthermore, locations "B" and "E" showed highly elevated levels of dissolved oxygen. Conductivity values remained less than 100 $\mu \mathrm{Scm}-1$ throughout the reservoir while, location "C" showed the maximum value of $86.3 \mu \mathrm{S} \mathrm{cm}-1$ during the dry season.

The concentration of nitrate, nitrite and ammonia of the reservoir ranged between 0.8-2.6 $\mathrm{mg} \mathrm{l}^{-1}, 42.5-125.3 \mu \mathrm{g}^{-1}$ and 58.9-84.1 $\mu \mathrm{g} 1^{-1}$, respectively. Comparatively high amount of nitrate, nitrite and ammonia were observed in locations: "C", "D" and "E". During the study, TP ranged between 20.5$42.3 \mu \mathrm{g} 1^{-1}$ and DP between 1.6-5.3 $\mu \mathrm{g}^{-1}$. Average values of TP were $28.30 \mu \mathrm{g}^{-1}$ during the wet season and $33.60 \mu \mathrm{g} 1^{-1}$ during the dry season. High amounts of TP and DP were observed in locations: "C" and " $D$ ". The lowest DO value recorded in the study was 6.2 $\mathrm{mg} \mathrm{l}^{-1}$ in location "C". Conductivity in Kotmale Reservoir ranged between 48.0-86.3 $\mu \mathrm{S} \mathrm{cm}-1$ with average values of $63.1 \mu \mathrm{S} \mathrm{cm}$ during the wet season and $67.6 \mu \mathrm{S} \mathrm{cm}^{-1}$ during the dry season. The recorded $\mathrm{pH}$ range was 7.2-8.3 with the average values of 7.8 during the wet season and 7.9 during the dry season. However, our results indicated that the concentration of chlorophyll-a ranged between 18.2-65.0 $\mu \mathrm{g} \mathrm{l}^{-1}$ with average values of $32.1 \mu \mathrm{g}$ ${ }^{1-1}$ during the wet season, and $42.9 \mu \mathrm{g} \mathrm{l}^{-1}$ during the dry season.

Table 3 Pearson correlation matrix on transformed physic-chemical variables with Bonferroni adjusted probabilities for 13 physic-chemical variables in the 5 locations of Kotmale Reservoir during (a) wet season and (b) dry season. *significant correlation at $p=0.05$

\begin{tabular}{|c|c|c|c|c|c|c|c|c|c|c|c|c|c|}
\hline $\begin{array}{l}\text { Physico } \\
\text { chemical } \\
\text { Variables }\end{array}$ & $\mathrm{T}$ & $\mathrm{TB}$ & $\mathrm{PH}$ & $\mathrm{CON}$ & ALK & NTI & NTA & $\mathrm{AM}$ & $\mathrm{TP}$ & $\mathrm{DP}$ & SO & DO & $\mathrm{CH}$ \\
\hline \multicolumn{14}{|c|}{ Wet season } \\
\hline $\mathrm{T}$ & 1 & & & & & & & & & & & & \\
\hline TB & $0.76 *$ & 1 & & & & & & & & & & & \\
\hline $\mathrm{PH}$ & 0.48 & 0.59 & 1 & & & & & & & & & & \\
\hline $\mathrm{CON}$ & $0.74 *$ & $0.96 *$ & $0.75^{*}$ & 1 & & & & & & & & & \\
\hline ALK & 0.64 & 0.51 & 0.7 & 0.5 & 1 & & & & & & & & \\
\hline NTI & 0.66 & $0.95 *$ & 0.36 & 0.89* & 0.23 & 1 & & & & & & & \\
\hline NTA & 0.48 & 0.15 & -0.53 & -0.05 & 0.01 & 0.26 & 1 & & & & & & \\
\hline $\mathrm{AM}$ & 0.65 & $0.83 *$ & 0.27 & 0.66 & 0.6 & $0.77 *$ & 0.43 & 1 & & & & & \\
\hline $\mathrm{TP}$ & $0.96 *$ & $0.91 *$ & 0.61 & $0.89 *$ & 0.67 & $0.8^{*}$ & 0.32 & $0.76 *$ & 1 & & & & \\
\hline DP & 0.09 & 0.69 & 0.53 & $0.72 *$ & 0.07 & $0.7^{*}$ & -0.46 & 0.41 & 0.35 & 1 & & & \\
\hline SO & 0.65 & 0.13 & -0.13 & 0.01 & 0.51 & 0.05 & $0.8^{*}$ & 0.43 & 0.46 & -0.61 & 1 & & \\
\hline DO & 0.04 & -0.37 & -0.7 & -0.56 & 0 & -0.33 & 0.79* & 0.11 & -0.16 & $-0.8^{*}$ & $0.76 *$ & 1 & \\
\hline $\mathrm{CH}$ & -0.12 & 0.41 & 0.6 & 0.42 & 0.42 & 0.26 & -0.64 & 0.38 & 0.14 & $0.75^{*}$ & -0.48 & -0.59 & 1 \\
\hline \multicolumn{14}{|c|}{ Dry season } \\
\hline $\mathrm{T}$ & 1 & & & & & & & & & & & & \\
\hline $\mathrm{TB}$ & 0.1 & 1 & & & & & & & & & & & \\
\hline $\mathrm{PH}$ & 0.79* & 0.53 & 1 & & & & & & & & & & \\
\hline $\mathrm{CON}$ & 0.16 & 0.99* & 0.55 & 1 & & & & & & & & & \\
\hline ALK & 0.08 & $\mathbf{0 . 7 4} *$ & 0.53 & 0.62 & 1 & & & & & & & & \\
\hline NTI & 0.57 & 0.14 & $0.74 *$ & 0.22 & -0.01 & 1 & & & & & & & \\
\hline NTA & 0.1 & 0.59 & 0.2 & 0.5 & $0.75^{*}$ & -0.5 & 1 & & & & & & \\
\hline $\mathrm{AM}$ & -0.1 & 0.95* & 0.47 & $0.9 *$ & $0.78 *$ & 0.19 & 0.46 & 1 & & & & & \\
\hline $\mathrm{TP}$ & -0.04 & 0.67 & -0.02 & 0.66 & 0.38 & -0.51 & $\mathbf{0 . 7 9} *$ & 0.47 & 1 & & & & \\
\hline DP & -0.56 & 0.5 & -0.3 & 0.55 & -0.06 & -0.13 & -0.05 & 0.52 & $\mathbf{0 . 7 9} *$ & 0.47 & & & \\
\hline SO & -0.02 & 0.04 & 0.07 & -0.11 & 0.66 & -0.45 & 0.68 & 0.09 & -0.05 & 0.52 & 1 & & \\
\hline DO & -0.36 & $-0.72 *$ & $\mathbf{- 0 . 8 4} *$ & -0.72 & -0.6 & $-0.74 *$ & -0.07 & $-0.78 *$ & 0.02 & -0.14 & 0.09 & 1 & \\
\hline $\mathrm{CH}$ & -0.27 & 0.21 & 0.18 & 0.23 & 0.01 & 0.63 & -0.59 & 0.43 & -0.45 & 0.44 & -0.48 & -0.61 & 1 \\
\hline
\end{tabular}

$\mathrm{T}$, Temperature $\left({ }^{\circ} \mathrm{C}\right)$; TB, Turbidity (NTU); $\mathrm{PH}, \mathrm{pH}$ value; CON, Conductivity $\left(\mu \mathrm{S} \mathrm{cm}^{-1}\right)$; ALK, Total Alkalinity $\quad\left(\mathrm{mg} \mathrm{l}^{-1}\right)$; NTI, Nitrite $\left(\mu \mathrm{g} \mathrm{l}^{-1}\right)$; NTA, Nitrate $\left(\mathrm{mg} \mathrm{l}^{-1}\right)$;AM, Ammonia $\left(\mu \mathrm{g} \mathrm{l}^{-1}\right)$; Total Phosphorous, TP $\left(\mu \mathrm{g} \mathrm{l}^{-1}\right)$; DP, Dissolved Phosphorus $\left(\mu \mathrm{g} \mathrm{l}^{-1}\right)$; SO, Sulphate $\left(\mathrm{mg} \mathrm{l}^{-1}\right)$, DO, Dissolved Oxygen $\left(\mathrm{mg} \mathrm{l}^{-1}\right)$; $\mathrm{CH}$, chlorophyll-a $\left(\mu \mathrm{g} \mathrm{l}^{-1}\right)$ (values in bold are significantly correlated at $p=0.05$ ). 


\section{A.L. Warusawithana and S.K. Yatigammana}

Pearson correlation for measured limnological parameters for the wet and dry seasons is summarized in Table 3. Accordingly, turbidity is positively and significantly correlated to temperature, conductivity, nitrite, ammonia and total phosphorous (TP) during the wet season. However, during the dry season, conductivity, alkalinity and ammonia are positively and significantly correlated to the turbidity level, while dissolved oxygen (DO) is negatively and significantly correlated. Furthermore, values ofchlorophyll-a significantly correlated only with the dissolved phosphorus (DP) levels.

In addition, TP significantly correlates with temperature, conductivity and turbidity. However, during the dry season strength of the relationships has reduced. Although elevated

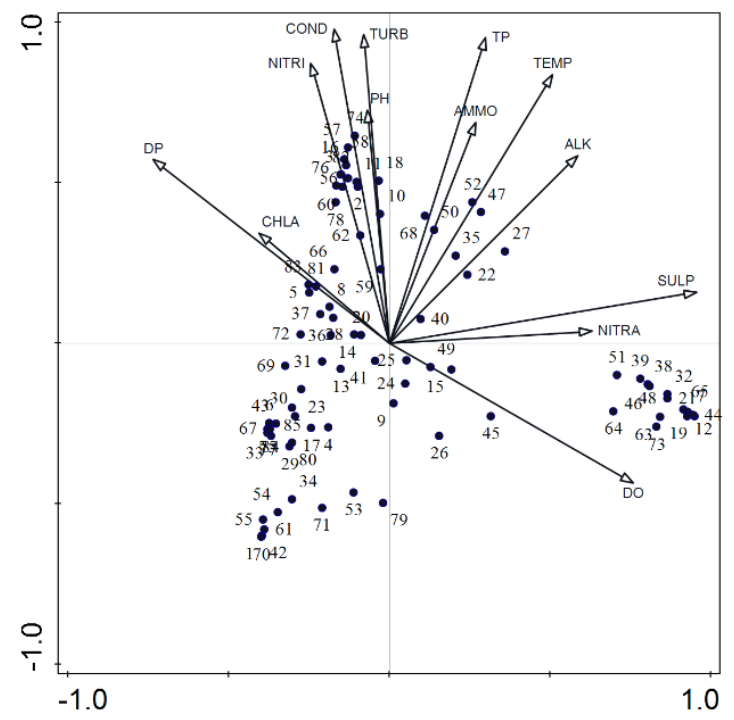

values are recorded during the dry season, there is no clear pattern for sulphate $\left(\mathrm{SO}_{4}{ }^{2-}\right)$ values.

\section{Ecology of Plankton}

Canonical Correspondence Analysis (CCA) results (Figure 3) for both phytoplankton and zooplankton revealed that the most important environmental variable(s) that explained the species variation are nutrients, especially nitrogen and phosphorus (Figure 3). It has revealed that the total variation for phytoplankton and zooplankton are 0.70908 and 0.92175 , respectively with the explanatory variables account for $100.0 \%$ (adjusted explained variation is $0.0 \%$ ).

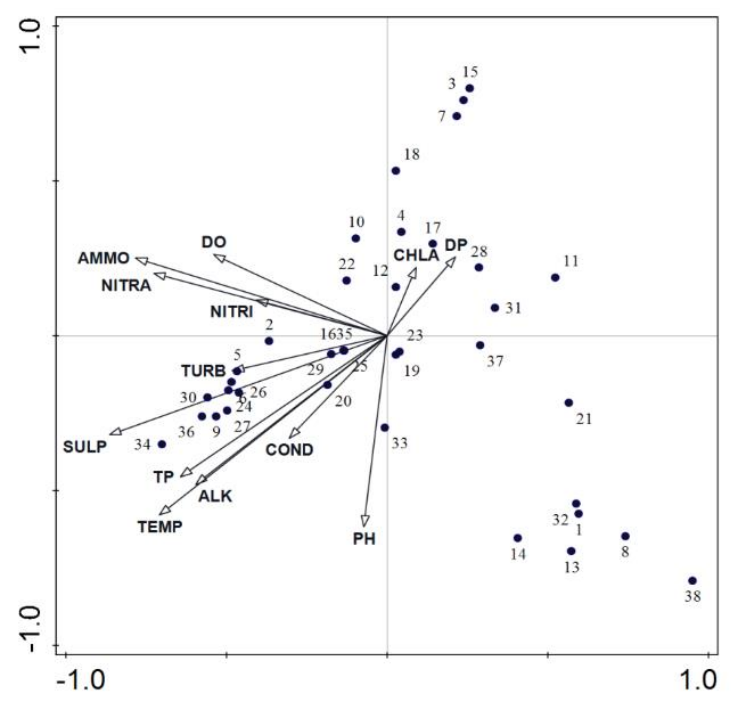

Fig 3 CCA diagram showing the distribution of phytoplankton (left) and zooplankton (right) along the $1^{\text {stand }} 2^{\text {nd }}$ ordination axeses

In this context, CCA showed the distribution of the majority of taxa lies in the opposite direction; however, sensitive species increase their number along the nutrient gradient. Accordingly,

Botryococcus braunii seemed to prefer higher nutrients, $\mathrm{pH}$ and conductivity that exist in locations "D" and "E". Furthermore, Navicula sp. positively correlated with the amount of dissolved oxygen while negatively correlated with $\mathrm{pH}$, turbidity, conductivity, amount of nitrite and phosphate. Microcystis sp. were positively correlated with the higher values of $\mathrm{TP}$, ammonia, conductivity and turbidity that exist in location "C".

Moreover, the numerical density of Chydorus sphaericus and, Filinia longiseta has negatively correlated with DO, conductivity and excessive amounts of nutrients. Furthermore, the abundance of K. tropica positively correlated to nutrients and dissolved oxygen content while negatively correlated to $\mathrm{pH}$, which is evident in location "C". Brachionus sp. positively correlated with conductivity, turbidity, $\mathrm{pH}$ and excessive amounts of nutrients.

According to the performed two-way ANOVA, the calculated p-values for locations vs. each plankton groups (except for copepoda, insect larva and nematoda) were less than " $\alpha$ " set value $(\mathrm{p}=0.05)$. Similarly, calculated $\mathrm{p}$-values for different study sites (e.g: sites in location $\mathrm{A}$ are $A_{1}, A_{2}, A_{3}$ and $A_{4}$ ) in each location, for each plankton groups were less than " $\alpha$ " set value 


\section{A.L. Warusawithana and S.K. Yatigammana}

$(\mathrm{p}=0.05)$ except for ciliates and insect larvae. In other words, each plankton group showed significant differences in their RA among the different locations and among the different study sites. Furthermore, some plankton groups (or plankton species) showed highly remarkable deviation pattern in the selected location and also among the different sites within a selected location. However, actually, four different sites within a location did not show any remarkable deviation among the sites. Furthermore, calculated p-values for study time period (years) vs. each plankton group for all locations were greater than " $\alpha$ " set value $(\mathrm{p}=0.05)$. On the other hand, any plankton group did not show a statistically significant difference in RA along a temporal gradient of three consecutive years for each location. Moreover, calculated p-values for interaction between locations and time (years) for all plankton groups were greater than " $\alpha$ " set value and therefore, the interaction between location and time (years) for all plankton groups was not statistically significant.

\section{DISCUSSION}

\section{Distribution and abundance of plankton}

Although the Kotmale Reservoir supports a high diversity of phytoplankton and zooplankton, many locations are dominated by only a few species. Moreover, the abundance of a particular phytoplankton/zooplankton species is also varied location to location.

Desmids and diatoms are hardly observed or not to be expected in polluted waters (Piyasiri 1995; Perera and Piyasiri 1998). According to $\mathrm{Wu}$ (1984) diatoms dominate in oligotrophic waters. In addition, desmids also tend to occur mainly in oligotrophic water. Such generalizations are not absolute, however, since some desmids (e.g. Cosmarium meneghinii, Staurastrum spp.) are typical of mesotrophic and eutrophic lakes (Bellinger and Sigee 2010). Accordingly, high dominance of desmid and diatom species such as Cosmarium spp. and Staurastrum spp. could be an indication that the Kotmale Reservoir is in the mesotrophic conditions. Contrary to that situation, higher dominance of some diatom species such as Aulacoseira granulata which is known to appear in blooms in eutrophic freshwater around the world (Nogueira and Matsumura-Tundisi 1996) indicate that the Kotmale Reservoir is moving towards the eutrophication.
Piyasiri (1995) and, Perera and Piyasiri (1998) noticed that the phytoplankton communities of newly built upland reservoirs of the river Mahaweli are dominated by the family Chlorophyceae, especially by Staurastrum species. Although desmids are well known indicators of oligotrophic water, Staurastrum sp. are typical of mesotrophic and eutrophic lakes (Bellinger and Sigee 2010). In our study, locations "A" and "B" are dominated with Staurastrum sp. where comparatively high nutrient content was recorded. The most abundant phytoplankton species encountered in the reservoir was Aulacoseira granulata which usually appear in blooms in eutrophic and hypereutrophic fresh water around the world (Nogueira and Matsumura-Tundisi 1996; Bucka et al. 2003; Weis et al. 2008; Bellinger and Sigee 2010). In addition, A. granulate also known to tolerate a wide range of limnological conditions including $\mathrm{pH}$, temperature, conductivity, dissolved oxygen, amount of nitrate and phosphate. Physic-chemical data clearly indicate that the locations: "D" and "E" of the reservoir where A. granulata was abundant are eutrophic and recorded with the highest TP values.

In contrast, Microcystis sp. is also abundant in the Kotmale Reservoir, especially, in location "C". Physic-chemical data clearly indicate that location " $\mathrm{C}$ " is eutrophic, with comparatively high TP, DP, ammonia, conductivity and turbidity values. Sakset and Chankaew (2013) recorded that Microcystis sp. is usually found in polluted water with high phosphate content and could be used as indicators of eutrophic water. Further, Kumari et al. (2008) found that Microcystis sp. is usually found in waters with high amounts of organic contaminants. Bellinger and Sigee (2010) indicated that Microcystis sp. is predominated in eutrophic water and the bloom is indicative of pre-existing high nutrient status. Under eutrophic conditions, they tend to reproduce explosively forming algal blooms due to high nutrient content. For instance, a thick bloom of Microcystis aeruginosa was recorded in the Kotmale Reservoir in 1991 (Piyasiri 1995). Because of A. granulata is a tolerable species known to survive under a wide range of extreme environmental condition, the presence of Microcystis sp. may not have an effect on A. granulata. It could be the reason why two species survive together or dominate in different localities in the reservoir.

It was found that B. braunii was well abundant in location " $\mathrm{D}$ " where high levels of 


\section{A.L. Warusawithana and S.K. Yatigammana}

$\mathrm{pH}, \mathrm{TP}$ and conductivity were recorded while it was less abundant in location "E" with low levels of TP and conductivity. Therefore, it is apparent that B. braunii is sensitive to variations in $\mathrm{pH}$, TP and conductivity. Similar results are reported by Demura et al. (2014) and, Hifney and AbdelBasset (2014) in a study of modelling B. brauniipH and $\mathrm{CO} 2$ level. Further, Ruhland et al. (2003) found that B.braunii is common in nutrient rich eutrophic water as well.

High abundances of Fragellaria capucina and Navicula sp. were recorded in locations "D" and "E" where the nutrient rich water of Puna Oya and Pundalu Oya reach the reservoir, respectively. Previous studies have shown that Navicula was one of the best genera which can indicate organic pollution in water (Kumari et al. 2008; Bellinger and Sigee 2010; Sakset and Chankaew 2013). Similarly, Kumari et al. (2008) and Lotter et al. (1998) found that a Fragellaria sp. is a good water pollution indicator which helps find whether a waterbody moves from oligotrophic to mesotrophic. Although Dokulil (2003) and Wu (1984) stated that Fragilaria capucina is commonly found in oligotrophic water, the current study revealed that they are present in mesotrophic to eutrophic water in our tropical reservoir where the water temperature range was $24^{\circ} \mathrm{C}$ to $29^{\circ} \mathrm{C}$.

Previous studies on the composition of zooplankton in Mahaweli reservoirs indicated that it was mainly represented by copepods, cladocera and rotifers, while the species richness of copepods was less than that of the rotifers and cladocera (Piyasiri and Chandrananda 1998). Many authors (Lotter et al. 1998; Ferdous and Muktadir 2009; Raina et al. 2013) found that some protozoan species, such as Arcella sp., Difflugia sp., Paramoecium sp. can be considered as indicators of a low level of dissolved oxygen in the water. Moreover, cladocera species such as Alona spp., Chydorus spp. have also been considered as indicators of nutrient rich water (Lotter et al. 1998; Smol 2002; Bos and Cumming 2003; Ferdous and Muktadir 2009; Jain et al. 2010; Yatigammana and Cumming 2017). Accordingly, well an abundance of protozoa, cladocera, copepoda and rotifer can be considered as an indication that the Kotmale Reservoir is under the threat of developing the eutrophic condition.

Dominance of Brachionus sp. is also considered as an indication of eutrophic condition and the highest abundance was due to the presence of high levels of organic pollution (Lotter et al. 1998; Neto 2003; Kamaladasa and
Jayatunga 2007; Kumari et al. 2008; Sousa et al. 2008; Ferdous and Muktadir 2009; Mustapha 2010; Raina et al. 2013). In contrast, Saksena (1987) found that Brachionus sp. inhabits in moderately clean mesotrophic waters as well. Recorded physic-chemical data clearly indicated that the location "C" where Brachionus sp. was abundant is eutrophic with comparatively high levels of TP, DP, pH, ammonia, conductivity and turbidity.

On the other hand, (Kamaladasa and Jayatunga 2007; Sousa et al. 2008) found that the presence of Keratella tropica is an indication of freshwater eutrophication. Also, Filinia longiseta is considered as an indicator of higher trophic status (Sousa et al. 2008; Raina et al. 2013). Furthermore, (Sousa et al. 2008) recorded that nauplii and Ceriodaphnia sp. are also indicators of higher trophic status. In contrast, Saksena (1987), Holopainen (1992) and Offem et al. (2011) found that K. tropica is a good inhabitant of moderately clean oligotrophic to mesotrophic water. Ferdous and Muktadir (2009) have shown that K. tropica is also a good indicator of high turbidity along with Brachionus sp. However, current study revealed that Keratella sp. preferred high pH values. Holopainen (1992) also found that some Keratella species are $\mathrm{pH}$ sensitive and disappear in the course of acidification. Thus the presence of Keratella tropica, Filinia longiseta, Ceriodaphnia sp. and naupli in location " $\mathrm{C}$ " would be an indication of the reservoir is under the threat of developing eutrophication.

Presence of some cladocera species such as Chydorus sphaericus, Alona sp., Chydorus sp., chironomid and some crustacean larvae "nauplii" in location " $E$ " is an indication of eutrophication trend of the reservoir. Physic-chemical data clearly indicated that the location "E" with high values of ammonia, TP and DO runs towards the eutrophic condition. Similarly, use of Alona sp., Chydorus sphaericus and most of the other Chydorus sp. as pollution indicators are reported by Jain et al. (2010). Many of these cladocera possess the characteristic features of biological indicators such as sensitivity to environmental changes, quantifiable optima and tolerances, short generation time, making population turnovers easy to be detected (Swar and Fernando 1980; Raina et al. 2013; Yatigammana and Cumming 2017). In addition, Sousa et al. (2008) found that the naupli (larval form of Copepoda) is a good indicator of higher trophic status. Furthermore, chironomids have traditionally been used to classify water bodies 


\section{A.L. Warusawithana and S.K. Yatigammana}

based on their hypolimnetic oxygen levels related to trophic status and basin morphometry (Lotter et al. 1998; Smol 2002; Bos and Cumming 2003; Yatigammana and Cumming 2017).

Comparatively low levels of turbidity, conductivity and nutrients in location " $\mathrm{B}$ " indicate the relatively better water quality conditions. The reason could be due to low level of anthropogenic disturbances in the immediate catchment where it is declared as a forest reserve. Even though, the presence of Cyclops sp. in this location reflects its good water quality (Kumari et al. 2008; Ferdous and Muktadir 2009), presence of Chydorus sp. and Ceriodaphnia sp. may be a warning signal for trends for cultural eutrophication (Swar and Fernando 1980; Raina et al. 2013; Yatigammana and Cumming 2017). Moreover, the abundance of nematode species in the water column could support our idea of human induced nutrient enrichment which is consistent with the finding of Neto (2003). Although the location " $\mathrm{B}$ " declared as a reserved forest, it appears to receive some animal wastes of free ranging cattle or abandoned animals.

\section{Limnological (physic-chemical) variables of the Kotmale Reservoir}

A comparatively high amount of nitrate, nitrite and ammonia in locations: " $D$ " and " $E$ " may be due to the mixing of agrochemicals, especially both organic and inorganic fertilizer through agricultural runoff. Similarly, in location "C", decomposition of biota and domestic sewage account for high levels of nitrate. Sakset and Chankaew (2013) have also found that excessive sewage, fertilizers and high decomposition rate of biota in aquatic ecosystems directly enhance the amount of nitrate, nitrite and ammonia in water.

Total phosphorus (TP) of an aquatic system mainly consists of dissolved phosphorus (DP) which is mostly orthophosphate, and particulate forms of phosphorus (PP) including both inorganic and organic forms (Sharpely et al. 1994; Molisani et al. 2010). According to Raina et al. (2013), domestic wastewater and sewage could be the reason for high amounts of TP and DP in locations: "C" and "D". With reference to the TP ranges defined by various authors (Dokulil 2003; Sigee 2004; Bellinger and Sigee 2010) for oligotrophic, mesotrophic and eutrophic water conditions, it can be clearly justified that the Kotmale reservoir shows mesotrophic characteristics closer to eutrophic condition.

Dissolved oxygen (DO) content typically correlates with phytoplankton density of a lake, and primarily depends on the relative magnitude of photosynthetic oxygen generation and total plankton respiration (Kunlasak et al. 2013). The high DO values in location $\mathrm{E}$ could be related to higher photosynthetic activity by phytoplankton rather than macrophytes. Among the phytoplankton, filamentous algae and diatom, Aulacoseira granulata appear to govern the regulation of DO in the Kotmale Reservoir. According to Offem et al. (2011), enrichment of high organic pollutants in location "C", mainly due to massive human settlements and factories, could be the reason for low DO values. However, a water body can be accepted as suitable for plant growth, only if $\mathrm{DO}$ value lies within the range of 5.0-9.0 mg 1-1 (Offem et al. 2011). Accordingly, the water quality of the Kotmale Reservoir is still suitable for plant growth.

Higher conductivity values were recorded in locations " $\mathrm{C}$ " and " $\mathrm{D}$ " could be due to ground water and surface runoff from farm lands and human settlements. Furthermore, the addition of anions and cations through the use of agrochemicals and seasonings of soil may also be responsible. Deng et al. (2014) reported that $\mathrm{Cl}^{-}$, $\mathrm{SO}_{4}{ }^{2-}, \mathrm{K}^{+}, \mathrm{NO}_{2}{ }^{-}$and $\mathrm{NO}_{3}{ }^{-}$are the main ions that contribute to the variation in conductivity of surface water, which are a major component of agrochemicals (e.g. $\mathrm{NH}_{4} \mathrm{Cl}, \mathrm{KCl},\left(\mathrm{NH}_{4}\right)_{2} \mathrm{SO}_{4}$ and $\mathrm{K}_{2} \mathrm{SO}_{4}$ ). According to the range defined by Offem et al. (2011), the Kotmale Reservoir is still maintaining better water quality by showing very low levels of conductivity during both wet and dry seasons.

According to the $\mathrm{pH}$ ranges defined by Offem et al. (2011) for oligotrophic to eutrophic lakes, slightly alkaline mesotrophic nature of the Kotmale Reservoir indicates the productive nature which is favorable for well growth and survival of aquatic organisms (Raina et al. 2013). Higher $\mathrm{pH}$ values are suitable for maximum productivity of aquatic organisms. Thus, higher $\mathrm{pH}$ values recorded in location " $\mathrm{C}$ " could be due to the combined effect of agricultural run-off and photosynthetic activity of aquatic plants (Offem et al. 2011). According to Holopainen (1992) and Raina et al. (2013), low pH considerably reduces both phytoplankton species richness and community biomass (measured as chlorophyll-a concentration). Reduced phytoplankton biomass and species richness are in turn reflected in reduced zooplankton biomass due to lack of 


\section{A.L. Warusawithana and S.K. Yatigammana}

adequate food. Similarly, Mustapha (2010) also found that zooplankton prefers alkaline water. Chakraborty et al. (2011) found that the concentration of chlorophyll-a gradually increased from acidic to neutral water and reached its maximum $9.35 \mu \mathrm{g} \mathrm{l}-1$ at the alkaline $\mathrm{pH}$ of 8.15. Accordingly, high content of chlorophyll-a was reported in location " $\mathrm{C}$ " could be due to alkaline nature of water which promotes primary production. According to the chlorophyll-a ranges defined by various authors (Dokulil 2003; Sigee 2004; Bellinger and Sigee 2010), it can be stated that the Kotmale Reservoir is under the threat of developing the eutrophic condition.

\section{Ecology of Plankton}

Although, nutrients are essential to the functioning of healthy aquatic ecosystems, can exert negative effects at much higher concentrations by altering trophic dynamics, increasing algal biomass (Sharpely et al. 1994; Molisani et al. 2010), increasing turbidity, decreasing average DO concentrations and increasing fluctuations in $\mathrm{DO}$ and $\mathrm{pH}$. Such changes are caused by excessive nutrient concentrations, resulting in shifting the species composition away from functional assemblages of intolerant species towards less desirable assemblages of tolerant species (Molisani et al. 2010).

Canonical Correspondence Analysis (CCA) is a multivariate statistical technique used to reveal the relationships between the numerical density of biological assemblages of species and the abiotic variables in their environment (Neto et al. 2014). In this context, CCA showed the distribution of the majority of taxa lies in the opposite direction; however, sensitive species increase their number along the nutrient gradient. The CCA ordination obtained in our study is usually seen in eutrophic tropical lakes where the amount of DO shows a negative correlation with amount of nitrate (Molisani et al. 2010; Neto et al. 2014). When the amount of nitrate increases in a water body, nitrate preferring photosynthetic diatoms tend to form blooms reducing DO in water (Nogueira and Matsumura-Tundisi 1996; Bucka et al. 2003).

Preference of nutrients, $\mathrm{pH}$ and conductivity by Botryococcus braunii in locations " $D$ " and " $E$ " is consistent with the findings of Hifney and Abdel-Basset (2014) where they reported that Botryococcus braunii is sensitive to $\mathrm{pH}$ and $\mathrm{CO}_{2}$ level while it is common in nutrient rich eutrophic waters. In contrast, Navicula sp. positively correlates with the amount of dissolved oxygen while negatively correlating with $\mathrm{pH}$, turbidity, conductivity, amount of nitrite and phosphate. According to several research findings, Navicula sp. belongs to one of the best genera which can indicate organic pollution in water (Kumari et al. 2008; Bellinger and Sigee 2010; Sakset and Chankaew 2013). Bellinger and Sigee (2010), mention that this species preferred to be abundant in clay-turbid water. According to Van Dam et al. (1994), Navicula sp. is sensitive to DO which is similar to the saprobity values of the systems. It was distinguished that Navicula sp. is $\alpha$ mesosaprobous (oxygen saturation is $25-70 \%$ ) and tolerant to moderate to heavy organic pollution. Preference of higher values of TP, ammonia, conductivity and turbidity by Microcystis sp. in location "C" may be due to the reservoir receives nutrient rich water which appears to be received from human settlements, factories and agricultural areas with intensive use of agrochemicals. Similar results were found by two studies conducted in Kotmale Reservoir (Piyasiri 1995; Perera and Piyasiri 1998). Accordingly, the intensity of eutrophication has indicated by a thick bloom of Microcystis aeruginosain 1991, which occurred despite high flow rates. According to many authors, species belonging to Microcystis are known to exist in eutrophic to hyper-eutrophic waters (Dokulil 2003; Kumari et al. 2008; Bellinger and Sigee 2010; Sakset and Chankaew 2013). Since our result also showed similar findings, Botryococcus braunii, Aulacoseira granulata, Navicula sp. and Microcystis sp. can be suggested as environmental proxies to detect cultural eutrophication.

Chydorus sphaericus and, Filinia longiseta are considered as indicators of higher trophic status, because they prefer to exist in a low level of DO, conductivity and nutrients (Sousa et al. 2008; Raina et al. 2013). Some researchers found that Keratella tropica is an indicator of eutrophic conditions (Kamaladasa and Jayatunga 2007; Sousa et al. 2008). Similarly, Ferdous and Muktadir (2009) recorded that K. tropica is also a good indicator of high turbidity. Holopainen (1992) found that some Keratella species are sensitive to $\mathrm{pH}$ and disappear in the course of acidification. Accordingly, the abundance of $\mathrm{K}$. tropicain location " $\mathrm{C}$ " may be due to higher nutrients and dissolved oxygen with low $\mathrm{pH}$ value. In this location, the reservoir receives nutrient rich 


\section{A.L. Warusawithana and S.K. Yatigammana}

water which comes across mass human settlements, factories and agricultural farms with intensive use of agrochemicals. Not only that, dominance of Brachionus sp. is an indication of eutrophic condition and the highest abundance at location "C" could be due to the presence of high levels of organic pollution (Lotter et al. 1998; Neto 2003; Kamaladasa and Jayatunga 2007; Kumari et al. 2008; Sousa et al. 2008; Ferdous and Muktadir 2009; Mustapha 2010; Raina et al. 2013). Similarly, Neto (2003) found that dominance of Brachionus sp. are also associated with low water transparency due to high levels of dissolved organic matter. Since our results also detected similar findings, Chydorus sphaericus, Filinia longiseta, Keratella tropica and Brachionus sp. can be suggested as environmental proxies to detect cultural eutrophication.

Research involving planktons as environmental indicators are common in recent decades, mostly in the Western part of the world. Despite the importance of upgraded knowledge about the taxonomy of these organisms, morphological studies or literature on identification is not found in Sri Lanka, making the identification process more difficult at the local level. With species level indicators, inter analyst error in plankton identification is an important source of variation in assessments. One possible solution for the problem with taxonomic consistency is to use genus level indicators. Although such indicators have significant values, they do not work reliably in different locations and across larger geographic scales as species indicators (Kelly et al. 1995; Chessman et al. 1999; Hill et al. 2001). Even though with all the sources of error, plankton still stands out as a robust indicator globally because of the ability to be greatly transferable in space and time given the natural sampling and interanalyst sources of variability. Therefore, the findings of our study will help explain the sensitivity of various plankton taxa to important environmental variables. Hence, the results of the current study should definitely help environmental scientists to use plankton as proxy indicators of environmental prediction models.

\section{CONCLUSION}

The study revealed that some plankton species (e.g: Botryococcus braunii, Aulacoseira granulata, Fragellaria capucina, Chydorus sphaericus, Navicula sp., Microcystis sp.,
Brachionus sp., etc.) are significantly sensitive to environmental changes and prefer specific environmental conditions making thembe used to assess environmental conditions through the presence and absences or by abundance.

\section{ACKNOWLEDGEMENT}

National Science Foundation (NSF) for financial support (Grant No: RG/2008/EB/01).

\section{REFERENCES}

Abeysinghe, K. G. A. M. C. S. 2005. A model on forecasting physical, chemical and biological water quality parameters of Kotmale, Victoria, Randenigala and Rantambe reservoirs for monitoring against eutrophication, pollution and other purpose. M.Phil Thesis. University of Sri Jayawardenapura, Sri Lanka.

Baker, A.L. 2012. Phyco Key: An image based key to Algae (Protista), Cyanobacteria, and other aquatic objects. http://www.cfb.unh.edu/phycokey/phycokey. htm (accessed on 20 December 2013)

Bellinger, E. G. and D. C.Sigee (eds.). 2010. Freshwater Algae: Identification and use as Bioindicators. John Wiley and Sons, New York

Bos, D. G. and B. F. Cumming. 2003. Sedimentary cladocern remains and their relationship to nutrients and other limnological variables in 53 lakes from British Columbia, Canada. Canadian Journal Fish Aquatic Science 60: 1179-1189.

Bucka, H., E. Wilk-Wozniak and G. Pajak. 2003. A review: The similarities and differences of phytoplankton structure in the chooseneurtophic water bodies - Southern Poland. International Journal of Ecohydrology and Hydrobiology 3: 205-211.

Chakraborty, P., T. Acharyya, P. V. R. Babu and D. Bandhyopadhyay. 2011. Impact of salinity and $\mathrm{pH}$ on phytoplankton community in a tropical freshwater system: An investigation with pigment analysis by HPLC. Journal of Environment Monitoting 13: 614-620.

Chessman, B., I. Growns, J. Curry and PlunkettCole. 1999. Predicting diatom communities at the genus level for the rapid biological assessment of rivers. Freshwater Biology 41: 317-331. 


\section{A.L. Warusawithana and S.K. Yatigammana}

Costa, H. H. and P. K. De Silva. 1995. Limnological research and training in Sri Lanka: state of the art and future needs. Limnology of developing countries 1: 63-103.

Demura, M., M. Ioki, M. Kawachi, N. Nakajima and M. M. Watanabe. 2014. Desiccation tolerance of Botryococcusbraunii (Trebouxiophyceae, Chlorophyta) and extreme temperature tolerance of dehydrated cells. Journal of Applied Phycology 26: 4953.

Deng, J., B. Qin, H. W. Paerl, Y. Zhang, P. Wu, J. Ma, et al. 2014. Effects of Nutrients, Temperature and Their Interactions on Spring Phytoplankton Community Succession in Lake Taihu, China. PLoS One 9: 26-31.

Dodson, S. I. and D. J. Frey. 1991. Cladocera and other Branchiopoda. pp. 723-786. In: J. H. Thorp and P. Covich (eds). Ecology and classification of North American Fresh Water Invertibrates. Academic Press. San Diego,California.

Dokulil, M. T. 2003. Algae as ecological bioindicators. pp. 285-327. In: B. A. Markert, A. M. Breure and H. G. Zechmeister (eds). Bioindicator and bio-monitors. Elsevier Science, Amsterdam.

Ferdous, Z. and A. K. M. Muktadir. 2009. A Review: Potentiality of Zooplankton as Bioindicator. American Journal of Applied Sciences 6: 1815-1819.

Fernando, C. H. 1978. The freshwater invertebrate fauna of Sri Lanka. Spoliazeylanica 35: 15-42.

Fernando, C. H. 1993. Impact of Sri Lankan reservoirs, their conservation, fisheries and management. pp. 351-374. In: W. Eedelen, C. Preu, N. Ishwaran and C. M. MaddumaBandara (eds.) Ecology and landscape management of Sri Lanka.

Freeman, P. and P. S. Cranson. 1980. Family Chironomidae. Pp. 175-202. In: R.W. Crosskey (ed.) Catalogue the Diptera of the Afrotropical region. Bulletin of British Museum Natural History (Entomology)

Hall, R. I., P. R. Leavitt, R. Quinlan, A. X. Dixit and J. P. Smol. 1999. Effect of Agriculture urbanization and climate on water quality in northern Great Plains. Journal ofLimnology and Oceanography 44: 739-759.

Hann, B. J. 1990. Cladocera. In: B. G. Warner (ed.) Methods in Quaternary Ecology. Journal of Geoscience Canada 5: 81-90.

Hifney, A. F. and R. Abdel-Basset. 2014. Photosynthesis, respiration and carotenoid contents in the green alga
Botryococcusbraunii at elevated nutrient levels. Journal of Biology and Earth Sciences 4: 1-3.

Hill, B. H., R. J. Stevenson, Y. Pan, A. T. Herlihy, P. R. Kaufmann and C.B. Johnson. 2001. Comparison of correlations between environmental characteristics and stream diatom assemblages characterized at genus and species levels. Journal of North American Benthological Society 20: 299-310.

Holopainen, I. J. 1992. The effects of low pH on planktonic communities, Case history of a mall forest pond in eastern Finland. Journal of AnnalesZoologiciFennici 28: 95-103.

Jain, A., B. N. Singh, S. P. Singh, H. B. Singh and S. Singh. 2010. Exploring Biodiversity as Bioindicators for Water Pollution. National Conference on Biodiversity, Development and Poverty Alleviation. Uttar Pradesh State Biodiversity Board, Uttar Pradesh, Lucknow, India.

Kamaladasa, A. I. and Y. N. A. Jayatunga. 2007. Composition, density and distribution of zooplankton in south west and east lakes of Beira Lake soon after the restoration of south west lake. Ceylon Journal of Science (Biological Sciences) 36: 1-7.

Kelly, M. G., C. J. Penny and B. A. Whitton. 1995. Comparative performance of benthic diatom indices used to assess river water quality. Hydrobiologia 302: 179-188.

Kinross, J. 2000. Web Key: Desmids. http://www.algalweb.net/ desmid.htm (accessed on 21 December 2013)

Kumari, P., S. Dhadse, P. R. Chaudhari and S. R. Wate. 2008. A biomonitoring of plankton to assess quality of water in the lakes of Nagpur city. pp.160-164. In: Sengupta $M$ and Dalwani R (eds.). Proceeding of Taal 2007: The 12th World Lake Conference.Jaipur, Rajasthan, India.

Kunlasak, K., C. Chitmanat, N. Whangchai1, J. Promya and L. Lebel. 2013. Relationships of Dissolved Oxygen with Chlorophyll-a and Phytoplankton Composition in Tilapia Ponds. International Journal of Geosciences 4: 46-53.

Kutikova, L. A. 2002. Rotifera. pp. 23-68. In: C.H.Fernando (ed) A Guide to Tropical Freshwater Zooplankton. Backhugs Publishers, Leiden, Netherlands.

Lotter, A. F., H. J. B Birks, W. Hofmann and A. Marchetto. 1998. Modern diatom, cladocera, chironomid, and chrysophyte cyst assemblages as quantitative indicators for the reconstruction of past environmental 


\section{A.L. Warusawithana and S.K. Yatigammana}

conditions in the Alps. II. Nutrients. Journal of Paleolimnology 19:443-463.

Minisrty of Power and Renewable Energy, Sri Lanka. 2018. Performance 2017 and Programme for 2018. http://powermin.gov.lk/english/wpcontent/uploads/2017/10/MoPRE-2017.201803-English.pdf (accessed on 10 December 2017).

Molisani, M. M., H. S. Barroso, H. Becker, M. O. P. Moreira, C. A. G. Hijo, T. M. Monte and G. H. Vasconcellos. 2010. Trophic state, phytoplankton assemblages and limnological diagnosis of the Castanhão Reservoir, CE, Brazil. Journal of ActaLimnologicaBrasiliensia 22: 1-12.

Mustapha, M. K. 2010. Seasonal Influence of Limnological Variables on Plankton Dynamics of a Small, Shallow, Tropical African Reservoir. Asian Journal of Experimental Biological Sciences 1: 60-79.

Neto, V. F. D. F. P. 2003. Zooplankton as bioindicator of environmental quality in the tamandaré reef system (Pernambuco - Brazil): Anthropogenic influences and interaction with Mangroves. Ph.D. Thesis. University of Bremen, Germany.

Neto, A. J. G., L. C. da Silva, A. A. Saggio and O. Rocha. 2014. Zooplankton communities as eutrophication bioindicators in tropical reservoirs. Biota Neotropica 14: 1-12.

Nogueira, M. G. and T. Matsumura-Tundisi. 1996. Limnologia de um sistema artificial raso (Represa do Monjolinho - Sao Carlos, $\mathrm{SP})$ dinamica das populacoesfito e zooplanctonicas [Limnology of an artificial shallow system (Monjolinho Dam - São Carlos, SP): dynamics of phytoplankton and zooplankton populations] ActaLimnologicaBrasiliensia 8:149-168.

Offem, B. O., E. O. Ayotunde, G. U. Ikpi, S. N. Ochang and F. B. Ada. 2011. Influence of Seasons on Water Quality, Abundance of Fish and Plankton Species of Ikwori Lake, SouthEastern Nigeria. Journal of Fisheries and Aquaculture 13: 1-18.

Perera, N. and S. Piyasiri. 1998. Species Composition and Population Dynamics of the Phytoplankton Community in Kotmale Reservoir. Journal of the National Science Foundation of Sri Lanka 26: 293-309.

Piyasiri, S. 1995. Eutrophication and blue green algal bloom problem of Kotmale reservoir in Sri Lanka. pp 1-7. In: K.H. Timotius and F. Goltenboth. (eds). Tropical Limnology.
SatyaWacanaUniverity Press, Salatiga, Indonesia.

Piyasiri, S. and W. P. N. Chandrananda. 1998. Studies on the population structure of zooplankton in the kotmale reservoir. Journal of National Science Foundation of Sri Lanka 26: 59-76.

Raina, R., P. Kumar, F. Sonaullah and A. Wanganeo. 2013. Limnological study on a Samrat Ashok Sagar with special reference to zooplankton population. International Journal of Biodiversity and Conservation 5: 317-332.

Rajapaksha, R. 1981. A taxonomical study of the freshwater non-ChydoridCladocera (Crustacea: Cladocera) of Sri Lanka.M.Sc. Thesis, University of Waterloo, Ontario, Canada.

Ruhland, K. M., J. P. Smol, X. Wang and D. C. G. Muir. 2003. Limnological characteristics of 56 lakes in Central Canadian Arctic Tree line region. Journal of Limnology 62: 9-27.

Saksena, D. N. 1987. Rotifers as Indicators of Water

Quality. ActaHydrochimicaEtHydrobiologica 15: 481485.

Sakset, A. and W. Chankaew. 2013. Phytoplankton as a Bio-indicator of Water Quality in the Freshwater Fishing Area of Pak Phanang River Basin (Southern Thailand). Chiang Mai Journal of Scienc 40: 344-355.

Sharpley, A. N., S. C. Chapra, R. Wedepohl, J. T. Sim, T. C. Daniel and K. R. Reddy. 1994. Managing agricultural phosphorus for protection of surface waters: Issues and options. Journal of Environmental Quality 23: 437-451.

Sigee, D.C. (ed.). 2004. Freshwater microbiology: Biodiversity and dynamic interactions of microorganisms in the freshwater environment. John Wiley and Sons, New York.

Silva, E. I. L. and F. Schiemer. 2001. Human Factor: the fourth Dimension of reservoir limnology in tropics. pp 111-125. In: S. S. De Silva. (ed.). Reservoir and Culture -based Fisheries: Biology and management. ACIAR Publication, No. 98, Canberra, Australia.

Smol, J. P. (ed.). 2002. Pollution of Lakes and Rivers: A Paleoenvironmental perspective. Arnold, London and Oxford University Press, New York.

Sousa, W., J. L. Attayde, E. D. S. Rocha and E. M. Eskinazi-sant'anna. 2008. The response of zooplankton assemblages to variations in the water quality of four man-made lakes in semi- 
arid northeastern Brazil. Journal of Plankton Research 30: 699-708.

Swar, D. B and C. H. Fernando. 1980. Some studies on the ecology of limnetic crustacean zooplankton in Lake Begnas and Rupa, Pokhara valley, Nepal. Hydrobiologia 70: 235-245.

Van Dam, H., A. Mertens. \& J. Sinkeldam. 1994. A coded check-list and ecological indicator value of fresh water diatoms from the Netherlands. Netherland Journal of Aquatic Ecology 28: 117-127.

Verschuren, D., J. Tibby, K. Sabbe and N. Roberts. 2000. Effects of depth, salinity, and substrate on the invertebrate community of a fluctuating tropical lake. Journal of Ecology 81: 164-182.

Weis, J. J., D. S. Madrigal and B. J. Cardinale. 2008. Effects of Algal Diversity on the Production of Biomass in Homogeneous and Heterogeneous Nutrient Environments: A Microcosm Experiment. PloS ONE 3: e2825.doi.org/ 10.1371/journal.pone. 0002825

Wu, T.J. 1984. Phytoplankton as bioindicator for water quality in Taipei. Botanical Bulletin of Academia Sinica 25: 205-214.

Yatigammana, S and B. F. Cumming. 2017. Detecting recent limnological changes in two ancient reservoirs from Sri Lanka's Dry Zone using Cladocera. Fundamental and Applied Limnology 189: 351 - 363 . 